\title{
Effect of Liquid Pig Manure and Chemical Fertilizers on Shoot Growth and Nitrogen Status of Young “Fuyu” Persimmon Trees
}

\author{
Seong-Tae Choi*, Gwang-Hwan Ahn, Seong-Cheol Kim, Eun-Seok Kim \\ Sweet Persimmon Research Institute, Gyeongsangnam-Do Agricultural Research and Extension Services, Gimhae, Republic of \\ Korea \\ Email: *stchoi1234@korea.kr
}

How to cite this paper: Choi, S.-T., Ahn, G.-H., Kim, S.-C. and Kim, E.-S. (2017) Effect of Liquid Pig Manure and Chemical Fertilizers on Shoot Growth and Nitrogen Status of Young "Fuyu" Persimmon Trees. Journal of Agricultural Chemistry and Environment, 6, 144-151.

https://doi.org/10.4236/jacen.2017.63009

Received: August 1, 2017

Accepted: August 26, 2017

Published: August 29, 2017

Copyright $\odot 2017$ by authors and Scientific Research Publishing Inc. This work is licensed under the Creative Commons Attribution International License (CC BY 4.0).

http://creativecommons.org/licenses/by/4.0/

(c) (i) Open Access

\begin{abstract}
Liquid pig manure (LPM), digested from pig slurry, has been used as a nutrient source substituting chemical fertilizer (CF) for some crops. This experiment was conducted to evaluate the effect of different levels of CF and LPM in early July on nitrogen $(\mathrm{N})$ uptake of pot-grown young "Fuyu" persimmon (Diospyros kaki). The total $\mathrm{N}$ and potassium (K) from CF and LPM applied to a $3 \mathrm{~L}$ pot were $1.2 \mathrm{~g} \mathrm{~N}$ and $1.15 \mathrm{~g} \mathrm{~K}$ for the low and $2.4 \mathrm{~g} \mathrm{~N}$ and $2.3 \mathrm{~g} \mathrm{~K}$ for the high level. From 2 weeks after the applications, secondary shoots started to grow for the CF but none for the LPM. Two nutrient sources did not significantly affect the amount of $\mathrm{N}$ increase in different tree parts from July 1 to August 6. At the high level, tree total $\mathrm{N}$ increased by $80 \%$ from $551 \mathrm{mg}$ for the $\mathrm{CF}$ and by $31 \%$ from $583 \mathrm{mg}$ for the LPM. The nutrient sources did not affect soil $\mathrm{pH}$. The soil that received LPM contained more organic matter $(\mathrm{P}=$ 0.048), available phosphorus $(\mathrm{P})(\mathrm{P}=0.002)$, and exchangeable $\mathrm{K}^{+}(\mathrm{P}=0.001)$ and $\mathrm{Mg}^{2+}(\mathrm{P}=0.009)$ than the soil that received $\mathrm{CF}$ on August 6 . These results indicated that $\mathrm{N}$ in LPM becomes available later but its effect is more durable than CF.
\end{abstract}

\section{Keywords}

Liquid Pig Manure, Persimmon, Shoot Growth, Nitrogen Uptake, Nitrogen Partition

\section{Introduction}

The use of pig slurry as a source for plant nutrients has become of a serious interest in South Korea because its disposal is strictly monitored. Results of a 
number of studies indicated that LPM can be used as a nutrient source for crops as long as it is properly digested in a fermenting facility [1] [2]. Since LPM contains various inorganic nutrients which are necessary for crop growth [3] [4] [5], it is applied as a basal fertilizer especially for paddy rice [6] [7] and for fruit crops [8] [9]. Soil spreading of LPM, adjusted to contain $100 \%$ of $\mathrm{N}$ recommendation, was as effective as CFs in onion [2], rice [10], and pear [9]. No adverse effects of LPM on crop growth and soil properties were reported. While replacement of CFs with LPM in persimmon growing should undoubtedly have some merits, no comparative studies have been conducted with two different sources of nutrients for the trees. If CF can be substituted with LPM partially or completely in persimmon orchards, environmental pollution can be reduced from the illegal disposal of pig slurry and growers can save cost of supplying CF.

In persimmon orchards, similar amounts of $\mathrm{N}$ and $\mathrm{K}$ are supplied usually from June to July as supplemental fertilizers. Since persimmon trees are rather sensitive to $\mathrm{N}$ supply, not only an excessive $\mathrm{N}$ but the fast-acting $\mathrm{N}$ source may cause the occurrence of vigorous water sprouts and undesirable secondary shoot growth [11]. Excessive soil $\mathrm{N}$ is a major contributor of nitrate contamination of groundwater [12] [13]. On the other hand, if the $\mathrm{N}$ source is too slow to become available for the trees its effect on tree development may be less than desired: if $\mathrm{N}$ becomes available later in the season, it delays fruit maturation [14]. Therefore, when LPM is applied to persimmon orchard supplementally, it is important to understand the effect of different amounts of LPM on tree growth and N uptake within a certain time period rather than the whole season. Responses to $\mathrm{CF}$ and LPM applications in summer on $\mathrm{N}$ uptake have not been compared in other fruit crops. This experiment was conducted to evaluate the effect of different amounts of CF and LPM in summer on N uptake and secondary shoot growth of young persimmon trees.

\section{Materials and Methods}

\subsection{Materials}

Sixteen 2-year-old "Fuyu" trees were used for this experiment. The trees were grafted on one year old $D$. kaki seedlings grown in $3 \mathrm{~L}$ pots in spring two years ago and grown under a rain shelter in Sweet Persimmon Research Institute, Gimhae, South Korea. Pots, spaced at $50 \times 50 \mathrm{~cm}$, contained sandy loam soil and they were not fertilized until the treatment. The chemical properties of the pot soil before treatments are shown in Table 1. LPM used in this experiment was collected from an aerobically-digesting facility for pig slurry. Chemical properties of the LPM are shown in Table 2. Trees were supplied with about $0.7 \mathrm{~L} \cdot \mathrm{d}^{-1}$ water throughout the experiment with a sprinkler irrigation system.

\subsection{Treatment}

With two nutrient sources, CF and LPM, and two levels of each, the treatments were arranged in a $2 \times 2$ factorial design with three single-tree replicates using 
Table 1. Chemical properties of the soil used to evaluate application effect of chemical fertilizer and liquid pig manure. Soil was collected from pots grown with 2-year-old "Fuyu" persimmons before the treatments.

\begin{tabular}{ccccccc}
\hline $\mathrm{pH}$ & $\begin{array}{c}\text { Organic } \\
\text { matter } \\
\left(\mathrm{g} \cdot \mathrm{kg}^{-1}\right)\end{array}$ & $\begin{array}{c}\text { Total } \mathrm{N} \\
\left(\mathrm{g} \cdot \mathrm{kg}^{-1}\right)\end{array}$ & $\begin{array}{c}\text { Available } \mathrm{P} \\
\left(\mathrm{mg} \cdot \mathrm{kg}^{-1}\right)\end{array}$ & \multicolumn{3}{c}{ Exchangeable cation $\left(\mathrm{cmol}^{+} \cdot \mathrm{kg}^{-1}\right)$} \\
\hline 7.4 & 39.9 & 2.2 & 372 & $\mathrm{~K}$ & $\mathrm{Ca}$ & $\mathrm{Mg}$ \\
\hline
\end{tabular}

Table 2. Chemical properties of liquid pig manure used to compare with application effect of chemical fertilizer on 2-year-old "Fuyu" persimmons.

\begin{tabular}{ccccccc}
\hline \multirow{2}{*}{$\mathrm{pH}$} & $\begin{array}{c}\text { Organic } \\
\text { matter }\end{array}$ & Total N & Available P & $\mathrm{K}$ & $\mathrm{Ca}$ & $\mathrm{Mg}$ \\
\cline { 2 - 7 } & & \multicolumn{5}{c}{$\left(\mathrm{g} \cdot \mathrm{kg}^{-1}\right)$} \\
\hline 8.4 & 17.0 & 4.0 & 0.71 & 3.84 & 0.56 & 0.10 \\
\hline
\end{tabular}

twelve trees. An additional four trees were used for analysis at start of the experiment before the first treatment on July 1 . Each nutrient source at low and high levels was supplied to the pot on July 1, 3, and 5 in three equal aliquots. LPM of 300 (low) and $600 \mathrm{~mL}$ (high) was poured on soil surface of the pots on each treatment date. The treatment of LMP was established not to injure trees based on our preliminary study. For the CF treatment, urea and potassium chloride $(\mathrm{KCl})$ were fertigated with $1 \%(\mathrm{w} / \mathrm{v})$ solutions as was commonly done in the orchard. Urea and $\mathrm{KCl}$ were adjusted to have the equivalent amount of total $\mathrm{N}$ and $\mathrm{K}$ contained in the LPM. Uptake and partitioning of $\mathrm{K}$ were not of primary interest in this study, but it was nonetheless incorporated in this CF treatment to mimic the composition of the LPM. The total $\mathrm{N}$ and $\mathrm{K}$ supplied to a pot were 1.2 $\mathrm{g} \mathrm{N}$ and $1.15 \mathrm{~g} \mathrm{~K}$ for the low and $2.4 \mathrm{~g} \mathrm{~N}$ and $2.3 \mathrm{~g} \mathrm{~K}$ for the high level.

\subsection{Sampling, Plant Measurement and N Analysis}

Secondary shoot growth was monitored to assess the response of the trees to different nutrient sources and their levels. Four trees on July 1 and the remaining 12 trees on August 6 were destructively harvested and divided into various tree parts. $\mathrm{N}$ contents in July 1 samples served as the basis for comparison with those in August 6 samples. The trees were divided into leaves, aerial woods, and roots. Aerial woods were separated into shoots, secondary shoots, 1- to 2-year-old woods (old woods) while the roots were divided into small $(\leq 2)$ and large ones $(>2)$ according to their diameter in $\mathrm{mm}$. After drying at $80^{\circ} \mathrm{C}$ for $48 \mathrm{~h}$, the samples were ground with a Wiley mill (3383-L10; Thomas Scientific, Swedesboro, NJ) to pass through a 20-mesh screen. To determine total N, 0.2-g sub-samples were analyzed with a Kjeldahl instrument (Kjeltec 2300, Foss Co., Höganäs, Sweden) using the micro-Kjeldahl method [15]. By taking the concentration of $\mathrm{N}$ in the different tree parts and their dry weights (DWs), $\mathrm{N}$ contents in each part were calculated. Differences in the amount of $\mathrm{N}$ between July 1 and August 6 are considered the amount absorbed and distributed to different tree parts. 


\subsection{Soil Analysis}

Soil samples were collected from soils remained after excavating roots from four pots on July 1 before treatments and the remaining 12 pots on August 6. Organic matter and various elements were analyzed according to the Methods for Chemical Analysis of Soils and Plants [16]. Briefly, soil $\mathrm{pH}$ was measured with distilled water $\left(1: 5\right.$ with $\mathrm{H}_{2} \mathrm{O}$ ) with a $\mathrm{pH}$ meter (Orion 520A; Orion Research Inc., Boston, MA). Organic matter was measured by Tyurin method [17]. Total $\mathrm{N}$ content was determined after the Kjeldahl digestion. The available $\mathrm{P}$ was determined using the Lancaster method. Exchangeable $\mathrm{K}^{+}, \mathrm{Ca}^{2+}$, and $\mathrm{Mg}^{2+}$ were estimated by using inductively coupled plasma spectroscopy (Analyst 300; Perkin-Elmer, Norwalk, CT) after extracting with $1 \mathrm{M}$ ammonium acetate $\left(\mathrm{NH}_{4} \mathrm{OAc}\right)$.

\subsection{Statistical Analysis}

Statistical analyses were performed by analysis of variance using SAS software (version 8 for Windows; SAS Institute, Cary, NC).

\section{Results and Discussion}

\subsection{Secondary Growth and N Concentration in Different Tree Parts}

From 2 weeks after the treatments, unnecessary secondary shoots started to grow for the CF but none for the LPM. Treating with either the low or the high level of CF produced secondary shoots by August 6 (Figure 1), exhibiting the final DWs of 3.4 and $2.9 \mathrm{~g}$ per tree, respectively. Table 3 shows $\mathrm{N}$ concentrations in different tree parts measured on August 6 . $\mathrm{N}$ concentration was not significantly affected in all tree parts by different nutrient sources. However, $\mathrm{N}$ concentration was higher especially in shoots, old woods, and small roots at the high level of both CF and LPM. No occurrence of secondary shoot growth of the trees receiving LPM suggested that $\mathrm{N}$ uptake by those trees was slower than that by the
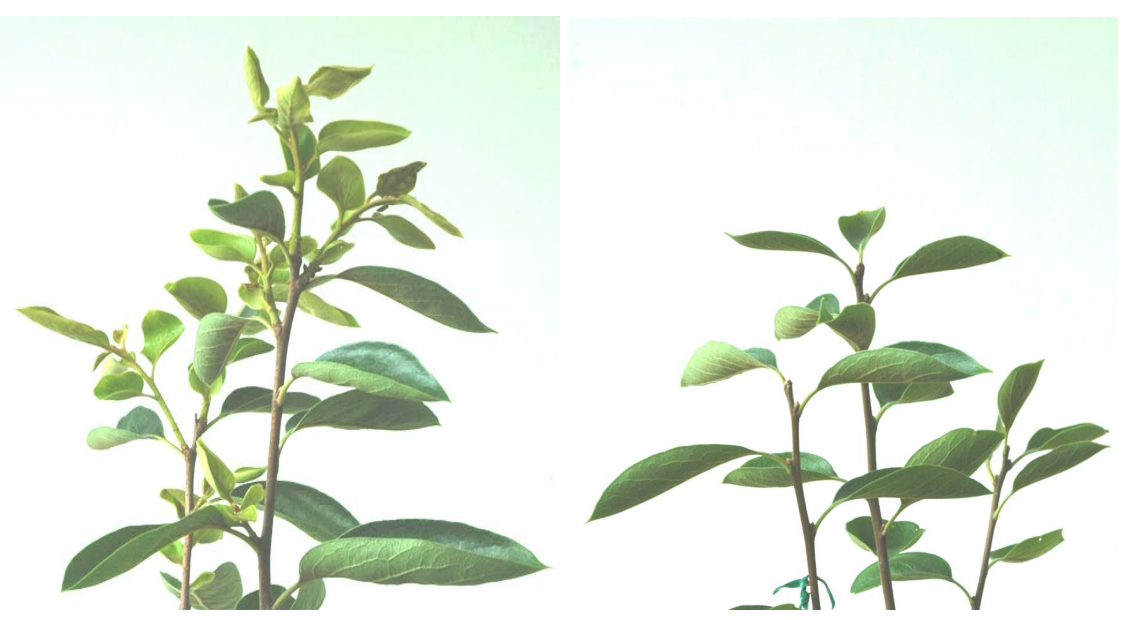

Figure 1. Shoot growth of 2-year-old "Fuyu" persimmons supplied with chemical fertilizer (left) or liquid pig manure (right) that contained $1.2 \mathrm{~g}$ nitrogen. No secondary shoots were grown when supplied with liquid pig manure. Photos were taken on Aug. 6. 
Table 3. Nitrogen $(\mathrm{N})$ concentration in different tree parts of 2-year-old "Fuyu" persimmon on August 6, $36 \mathrm{~d}$ after applications of chemical fertilizer (CF) and liquid pig manure (LPM) on July 1.

\begin{tabular}{|c|c|c|c|c|c|c|c|}
\hline \multicolumn{2}{|c|}{ Treatment } & \multirow{2}{*}{ Leaf } & \multicolumn{3}{|c|}{ Aerial wood } & \multicolumn{2}{|c|}{ Root } \\
\hline \multirow{2}{*}{ Source } & \multirow{2}{*}{$\begin{array}{l}\text { Level }^{\mathrm{b}} \\
\text { (g/tree) }\end{array}$} & & Shoot & $2^{\text {nd }}$ shoot & Old wood & Small & Large \\
\hline & & \multicolumn{6}{|c|}{$\mathrm{N}(\% \mathrm{DW})$} \\
\hline \multirow{2}{*}{$\mathrm{CF}^{\mathrm{a}}$} & Low & $2.17 \pm 0.04$ & $0.97 \pm 0.07$ & $1.56 \pm 0.1$ & $0.51 \pm 0.01$ & $0.96 \pm 0.08$ & $0.86 \pm 0.16$ \\
\hline & High & $2.20 \pm 0.02$ & $1.18 \pm 0.09$ & $1.58 \pm 0.1$ & $0.73 \pm 0.06$ & $1.43 \pm 0.29$ & $0.97 \pm 0.13$ \\
\hline \multirow{2}{*}{ LPM } & Low & $1.96 \pm 0.07$ & $0.78 \pm 0.07$ & - & $0.59 \pm 0.06$ & $1.13 \pm 0.07$ & $0.59 \pm 0.11$ \\
\hline & High & $2.12 \pm 0.15$ & $1.06 \pm 0.08$ & - & $0.70 \pm 0.04$ & $1.41 \pm 0.10$ & $0.90 \pm 0.11$ \\
\hline \multicolumn{2}{|c|}{ Source (S) } & NS & NS & & NS & NS & NS \\
\hline \multicolumn{2}{|c|}{ Application level (L) } & NS & * & & $* *$ & * & NS \\
\hline \multicolumn{2}{|c|}{$\mathrm{S} \times \mathrm{L}$} & NS & NS & & NS & NS & NS \\
\hline
\end{tabular}

${ }^{a} \mathrm{CF}$ : fertigated with urea and potassium chloride $(\mathrm{KCl})$ solution; ${ }^{b}$ Levels (g/pot): low, $1.2 \mathrm{~N}-1.15 \mathrm{~K}$; high, $2.4 \mathrm{~N}-2.3 \mathrm{~K}$. Data represented are means $\pm \mathrm{SE}$ ( $\mathrm{n}=$ 3). NS: non-significant, ${ }^{*}$ : significant at $\mathrm{P} \leq 0.05$, ${ }^{* *}$ : significant at $\mathrm{P} \leq 0.01$.

trees receiving CF. Excessive $\mathrm{N}$ uptake during summer would cause vigorous growth of water sprouts and secondary shoots with the concurrent deterioration of fruit quality [11] [18]. It appeared that LPM could be more favorable to keep tree vigor stable than $\mathrm{CF}$ as long as the method for its application was carefully controlled in terms of the time and quantity.

\subsection{Nitrogen Partition in a Tree}

Table 4 shows the amount of $\mathrm{N}$ absorbed and distributed to different tree parts between July 1 and August 6 . Two nutrient sources did not significantly affect the amount of $\mathrm{N}$ increase in different tree parts. Of the total aerial wood, $\mathrm{N}$ in secondary shoots accounted for $28 \%$ at the low and $17 \%$ at the high CF. At the high level of both CF and LPM, N increase tended to be higher in all tree parts except secondary shoots. A significant $\mathrm{N}$ increase was observed in the leaves $(\mathrm{P}=$ $0.044)$ and large roots $(\mathrm{P}=0.027)$ at the high level of application. Total $\mathrm{N}$ was $80 \%$ more for the CF (551 vs. $993 \mathrm{mg}$ ) and 31\% more for the LPM (582 vs. 766 mg per tree) at the high level. Considering that the trees that received LPM absorbed a similar amount of $\mathrm{N}$ to the ones that received CF (Table 4), LPM could be an acceptable supplemental source of nutrients as has been previously reported for nectarine [8] and pear [9]. Total $\mathrm{N}$ content per tree increased more with the high level of both LPM and CF, however, the extent of the increase was less with LPM than with CF. It appeared that, unlike CF, $\mathrm{N}$ in LPM was not readily available for the tree since it mostly exists in organic forms and it would require some time to mineralize them [3] [19].

\subsection{Chemical Properties of Soil}

It is of interest whether the LPM application changes chemical properties of the soil at the end of the experiment. The soil that received LPM contained more organic matter, available $\mathrm{P}$, and exchangeable $\mathrm{K}^{+}$and $\mathrm{Mg}^{2+}$ than the soil that received CF (Table 5). Organic matters in the LPM soils increased by 10 and 24\% 
Table 4. Nitrogen $(\mathrm{N})$ increase in different tree parts of 2-year-old "Fuyu" persimmon for $36 \mathrm{~d}$ after applications of chemical fertilizer (CF) and liquid pig manure (LPM) on July 1 . The $\mathrm{N}$ increase was calculated from $\mathrm{N}$ contents in different tree parts between July 1 and Aug. 6 by taking the concentration of $\mathrm{N}$ in the tree parts and their dry weights.

\begin{tabular}{|c|c|c|c|c|c|c|c|c|c|c|}
\hline \multicolumn{2}{|c|}{ Treatment } & \multirow{3}{*}{ Leaf } & \multicolumn{4}{|c|}{ Aerial wood } & \multicolumn{3}{|c|}{ Root } & \multirow{2}{*}{ Total } \\
\hline \multirow{2}{*}{ Source } & \multirow{2}{*}{ Level $^{\mathrm{b}}$} & & Shoot & $2^{\text {nd }}$ shoot & Old wood & Total & Small & Large & Total & \\
\hline & & & \multicolumn{8}{|c|}{$\mathrm{N}$ (mg/tree) } \\
\hline \multirow{2}{*}{$\mathrm{CF}^{\mathrm{a}}$} & Low & $218 \pm 4$ & $68 \pm 10$ & $53 \pm 14$ & $65 \pm 26$ & $186 \pm 44$ & $8 \pm 54$ & $138 \pm 10$ & $147 \pm 43$ & $551 \pm 36$ \\
\hline & High & $326 \pm 34$ & $77 \pm 20$ & $47 \pm 21$ & $148 \pm 43$ & $272 \pm 84$ & $218 \pm 82$ & $176 \pm 14$ & $395 \pm 93$ & $993 \pm 175$ \\
\hline \multirow{2}{*}{ LPM } & Low & $212 \pm 30$ & $69 \pm 25$ & 0 & $97 \pm 28$ & $166 \pm 32$ & $101 \pm 32$ & $104 \pm 19$ & $205 \pm 38$ & $583 \pm 58$ \\
\hline & High & $278 \pm 26$ & $87 \pm 19$ & 0 & $111 \pm 3$ & $198 \pm 17$ & $140 \pm 51$ & $150 \pm 19$ & $290 \pm 68$ & $766 \pm 75$ \\
\hline \multicolumn{2}{|c|}{ Source (S) } & NS & NS & $* *$ & NS & NS & NS & NS & NS & NS \\
\hline \multicolumn{2}{|c|}{ Application level (L) } & * & NS & NS & NS & NS & NS & * & * & * \\
\hline \multicolumn{2}{|c|}{$\mathrm{S} \times \mathrm{L}$} & NS & NS & NS & NS & NS & NS & NS & NS & NS \\
\hline
\end{tabular}

${ }^{\mathrm{a}} \mathrm{CF}$ : fertigated with urea and potassium chloride $(\mathrm{KCl})$ solution; ${ }^{\mathrm{b}}$ Levels $(\mathrm{g} / \mathrm{pot})$ : low, $1.2 \mathrm{~N}-1.15 \mathrm{~K}$; high, $2.4 \mathrm{~N}-2.3 \mathrm{~K}$. Data represented are means $\pm \mathrm{SE}(\mathrm{n}=$ 3). NS: non-significant, ${ }^{*}$ : significant at $\mathrm{P} \leq 0.05$, ${ }^{* *}$ : significant at $\mathrm{P} \leq 0.01$.

Table 5. Chemical properties of pot soils sampled on Aug. 6 as affected by applications of chemical fertilizer (CF) and liquid pig manure (LPM) on July 1 on 2-year-old "Fuyu" persimmons.

\begin{tabular}{|c|c|c|c|c|c|c|c|c|}
\hline \multicolumn{2}{|c|}{ Treatment } & \multirow{2}{*}{$\mathrm{pH}$} & \multirow{2}{*}{$\begin{array}{c}\text { Organic } \\
\text { matter } \\
\left(\mathrm{g} \cdot \mathrm{kg}^{-1}\right)\end{array}$} & \multirow{2}{*}{$\begin{array}{l}\text { Total N } \\
\left(\mathrm{g} \cdot \mathrm{kg}^{-1}\right)\end{array}$} & \multirow{2}{*}{$\begin{array}{c}\text { Available P } \\
\left(\mathrm{mg} \cdot \mathrm{kg}^{-1}\right)\end{array}$} & \multicolumn{3}{|c|}{ Exchangeable cation $\left(\mathrm{cmol}^{+} \cdot \mathrm{kg}^{-1}\right)$} \\
\hline Source & Level $^{\mathrm{b}}$ & & & & & K & $\mathrm{Ca}$ & $\mathrm{Mg}$ \\
\hline \multirow{2}{*}{$\mathrm{CF}^{\mathrm{a}}$} & Low & $7.4 \pm 0.1$ & $39.2 \pm 4.4$ & $1.28 \pm 0.32$ & $138 \pm 37$ & $0.151 \pm 0.02$ & $11.8 \pm 1.6$ & $1.58 \pm 0.12$ \\
\hline & High & $7.3 \pm 0.0$ & $37.3 \pm 1.0$ & $1.20 \pm 0.20$ & $155 \pm 4$ & $0.122 \pm 0.01$ & $10.3 \pm 1.0$ & $1.42 \pm 0.11$ \\
\hline \multirow{2}{*}{ LPM } & Low & $7.4 \pm 0.0$ & $43.0 \pm 2.6$ & $1.85 \pm 0.06$ & $278 \pm 58$ & $0.266 \pm 0.08$ & $11.4 \pm 0.8$ & $1.88 \pm 0.18$ \\
\hline & High & $7.4 \pm 0.1$ & $46.1 \pm 1.4$ & $1.74 \pm 0.02$ & $328 \pm 13$ & $0.607 \pm 0.08$ & $9.8 \pm 0.4$ & $1.93 \pm 0.05$ \\
\hline \multicolumn{2}{|c|}{ Source $(S)$} & NS & * & NS & $* *$ & ** & NS & $* *$ \\
\hline \multicolumn{2}{|c|}{ Application level (L) } & NS & NS & NS & NS & * & NS & NS \\
\hline \multicolumn{2}{|c|}{$\mathrm{S} \times \mathrm{L}$} & NS & NS & NS & NS & $* *$ & NS & NS \\
\hline
\end{tabular}

${ }^{a} \mathrm{CF}$ : fertigated with urea and potassium chloride $(\mathrm{KCl})$ solution; ${ }^{b} \mathrm{Levels}(\mathrm{g} / \mathrm{pot})$ : low, $1.2 \mathrm{~N}-1.15 \mathrm{~K}$; high, $2.4 \mathrm{~N}-2.3 \mathrm{~K}$. Data represented are means $\pm \mathrm{SE}$ ( $\mathrm{n}=$ 3). NS: non-significant, ${ }^{*}$ : significant at $\mathrm{P} \leq 0.05$, **: significant at $\mathrm{P} \leq 0.01$.

at the low and high levels, respectively, compared with those of the respective CF. Contents of available P and exchangeable $\mathrm{K}^{+}$for the LPM were $1.8 \sim 5$-fold higher than those for the respective $\mathrm{CF}$. Higher total $\mathrm{N}$ content was also observed in the LPM soils although not statistically significant. High contents of organic matter in the LPM soil on August 6 (Table 5) indicated that much of the organic matter still remained undecomposed in the soil by that time. Soil organic matters could slowly release inorganic nutrients through mineralization, the process of which helps to decrease the extent of nutrient leaching from irrigation [19]. Therefore, it is probable that the soil organic matter from the LPM could have contributed to significant increases of total $\mathrm{N}$, available $\mathrm{P}$, and exchangeable $\mathrm{K}^{+}$and $\mathrm{Mg}^{2+}$ in the soil. 


\section{Conclusion}

It is concluded that N in LPM becomes available later but its effect is more durable than CF. LPM application, adjusted to spread earlier in time and less in quantity, should thus be a satisfactory substitute for supplemental $\mathrm{N}$ supply in persimmon growing. More studies are needed to optimize the time and quantity of LPM under orchard conditions.

\section{Acknowledgements}

We gratefully acknowledge the financial support of "Cooperative Research Program for Agricultural Science \& Technology Development" (Project No. PJ010189022016) by Rural Development Administration, Republic of Korea.

\section{References}

[1] Choudhary, M., Bailey, L.D. and Grant, C.A. (1996) Review of the Use of Swine Manure in Crop Production: Effects on Yield and Composition on Soil and Water Quality. Waste Management and Research, 14, 581-595. https://doi.org/10.1177/0734242X9601400606

[2] Lee, J.T. and Seong, D.G. (2015) Replacing Conventional Nutrient Inputs for Basal Application with Anaerobically Digested Pig Slurry for Bulb Onion Production. Journal of Plant Nutrition, 38, 1241-1253. https://doi.org/10.1080/01904167.2014.991034

[3] Bernal, M.P. and Kirchman, H. (1992) Carbon and Nitrogen Mineralization and Ammonia Volatilization from Fresh, Aerobically and Anaerobically Treated Pig Manure during Incubation with Soil. Biology and Fertility of Soils, 13, 135-141.

[4] Lee, J.H., Go, W.R., Kunhikrishnan, A., Yoo, J.H., Kim, J.Y. and Kim, W.I. (2011) Chemical Composition and Heavy Metal Contents in Commercial Liquid Pig Manures. Korean Journal of Soil Science and Fertilizer, 44, 1085-1088. https://doi.org/10.7745/KJSSF.2011.44.6.1085

[5] Lee, S.B., Cho, K.M., Baik, N.H., Yang, C.H., Jung, J.H., Kim, K.J. and Lee, G.B. (2012) Effects of Pig Compost and Liquid Manure on Yield, Nutrients Uptake of Rice Plant and Physicochemical Properties of Soil. Korean Journal of Soil Science and Fertilizer, 45, 772-778. https://doi.org/10.7745/KJSSF.2012.45.5.772

[6] Jeon, W.T., Park, H.M., Park, C.Y., Park, K.D., Cho, Y.S., Yun, E.S. and Kang, U.G. (2003) Effects of Liquid Pig Manure Application on Rice Growth and Environment of Paddy Soil. Korean Journal of Soil Science and Fertilizer, 36, 333-343.

[7] Hong, S.G., Shin, J.D., Kwon, S.I., Park, W.K., Lee, D.B. and Kim, J.G. (2010) Effects of Co-Digestate Application on the Soil Properties, Leachate and Growth Responses of Paddy Rice. Journal of Korea Organic Resource Recycling Association, 18, 31-37.

[8] Beccaro, G.L., Cerutti, A.K., Donno, D. and Bounous, G. (2015) Nectarine Productivity and Fruit Quality under Swine Manure Fertilization: Results from a Three-Year Field Trial. Acta Horticulturae, 1084, 305-312. https://doi.org/10.17660/ActaHortic.2015.1084.43

[9] Park, J.M., Lim, T.J. and Lee, S.E. (2012) Effect of Pig Slurry Application on the Mineral Content of Leaf, Fruit Quality and Soil Chemical Properties in Pear Orchard. Korean Journal of Soil Science and Fertilizer, 45, 209-214. https://doi.org/10.7745/KJSSF.2012.45.2.209 
[10] Ryoo, J.W., Park, C.H. and Yoon, T.H. (2012) Effect of Growth and Yield with SCB Leachate Application Rates in Rice. Korean Journal of Organic Agriculture, 20, 631-642. https://doi.org/10.11625/KJOA.2012.20.4.631

[11] Choi, S.T., Park, D.S., Hong, K.P. and Kang, S.M. (2011) Summer Pruning Effect on Tree Growth and Fruit Production of Persimmon. Advances in Horticultural Science, 25, 164-169.

[12] Phan, T., Zheng, S.H., Iwaya-inoue, M., Furuya, T. and Fukuyama, M. (2007) Effects of Thermophilic Sewage Sludge Compost on Early Growth of Tall Fescue (Festuca arundinacea Schreb.) and Nitrogen Leaching Losses. Grassland Science, 53, 55-60. https://doi.org/10.1111/j.1744-697X.2007.00067.x

[13] Sieling, K., Schroder, H., Finck, M. and Hanus, H. (1998) Yield, N Uptake, and Apparent N-Use Efficiency of Winter Wheat and Winter Barley Grown in Different Cropping Systems. The Journal of Agricultural Science, 131, 375-387. https://doi.org/10.1017/S0021859698005838

[14] Choi, S.T., Park, D.S., Cho, Y.C. and Kang, S.M. (2009) Tree Responses of "Fuyu" Persimmon to Urea Nitrogen Applied at Different Times during the Late Season. Acta Horticulturae, 833, 307-312. https://doi.org/10.17660/ActaHortic.2009.833.49

[15] Nelson, D.W. and Sommers, L.E. (1973) Determination of Total Nitrogen in Plant Material. Agronomy Journal, 65, 109-112. https://doi.org/10.2134/agronj1973.00021962006500010033x

[16] National Institute of Agricultural Science and Technology (2000) Methods for Chemical Analysis of Soil and Plant. NIAST, Suwon.

[17] Schollenberge, C.J. (1927) A Rapid Approximate Method for Determining Soil Organic Matter. Soil Science, 24, 65-68. https://doi.org/10.1097/00010694-192707000-00008

[18] Park, D.S., Kang, S.M., Choi, S.T., Lim, C.A. and Song, W.D. (2003) Effect of Secondary-Shoot Prunings on Fruit Growth and Following Year's Fruit Set of "Fuyu" Persimmon. Journal of Korean Society for Horticultural Science, 44, 678-682.

[19] Johnston, J. (2011) The Essential Role of Soil Organic Matter in Crop Production and the Efficient Use of Nitrogen and Phosphorus. Better Crops, 95, 9-11.

\section{Scientific Research Publishing}

Submit or recommend next manuscript to SCIRP and we will provide best service for you:

Accepting pre-submission inquiries through Email, Facebook, LinkedIn, Twitter, etc. A wide selection of journals (inclusive of 9 subjects, more than 200 journals)

Providing 24-hour high-quality service

User-friendly online submission system

Fair and swift peer-review system

Efficient typesetting and proofreading procedure

Display of the result of downloads and visits, as well as the number of cited articles

Maximum dissemination of your research work

Submit your manuscript at: http://papersubmission.scirp.org/

Or contact jacen@scirp.org 